\title{
COLLABORATIVE ECONOMY AT THE LEVEL OF THE EUROPEAN UNION: STATE AND PERSPECTIVES
}

\author{
Žarko ĐORIĆ $^{1}$ \\ ${ }^{1}$ High School of Vocational Studies in Criminology and Security, 18000 Niš, 80 - 84, Bulevar Svetog cara \\ Konstantina, the Republic of Serbia \\ E-mail: zdjoric82@gmail.com
}

Paper received: 29.09.2021.; Paper accepted: 15.11.2021.

\begin{abstract}
On the whole, the collaborative economy, as a recently emerging and fast-growing phenomenon, involves the exchange of resources using an online platform to produce, distribute and provide new services. Given the strong influence on shaping future labor market policies, labor relations, education and training, as well as digitalization, there is no doubt that the collaborative economy is one of the hot topics on today's political agenda, not just in Europe, but worldwide. It could be freely said that the collaborative economy in the European Union is a very current topic and numerous discussion papers are circulating about it, which all point to the general conclusion that this new model has not been developed in a meaningful way in this part of the world. In that sense, the primary goal of this paper is to analyze the mechanism of functioning of the collaborative economy, with special emphasis on the possibilities and limitations of its development at the EU level, applying scientific methods of systematization and analysis. The paper shows that the collaborative economy has not yet experienced its full valorization at the EU level, and at the same time presents conclusions and recommendations regarding its development potential in this part of the world. The paper suggests that the European Union has a positive attitude towards the collaborative economy, considering it an opportunity, not a threat, although there is a huge space for further economic expansion of this business model (in terms of employment, growth, competitiveness, sustainability and transition to the circular economy), as well as for a substantial shift in the field of its regulation in order to avoid serious bifurcation. In order for the collaborative economy at the EU level to take major steps forward in the forthcoming period, the most important thing is to establish a clear and dynamic legal environment, in order to avoid the risk of fragmentation of the single market and unfair competition.
\end{abstract}

Keywords: Collaborative economy; European Union; Regulation; Lasting sustainability; COVID-19.

\section{INTRODUCTION}

In recent times, collaborative economy (or sharing economy) is raised as a very controversial and actual topic. The collaborative economy involves three categories of actors: (i) service providers who share assets, resources, time and/or skills - these can be private individuals offering services on an occasional basis (peers) or service providers acting in their professional capacity (professional services providers); (ii) users of these; and (iii) intermediaries that connect - via an online platform - providers with users and that facilitate transactions between them (collaborative platforms) (Bergh, Funcke, \& Wernberg, 2021;
Botsman, \& Rogers, 2010; Bradley, \& Pargman, 2017; Codagnone, \& Bertin, 2016; Frenken, \& Schor, 2017; Gawel, MAchur, \& Pennington, 2016; Görög, 2018; Lee et al. 2016; Martin, 2015; Matofska, 2015; Petropoulos, 2017; Slee, 2015; Stephany, 2015; Sundararajan, 2016; Yaraghi, \& Shamika, 2017).

The paper starts from the basic premise according to which the collaborative economy of the European Union has not yet experienced its full momentum and affirmation, and on the basis of the above, an appropriate conclusion will be reached on its condition, with recommendations for its improvement. As this model of economy is 
relatively new and its growth comes with the advancement of technology, only secondary data sources, i. e. online literature sources such as internet articles and web sources, were used for the theoretical and research part of the paper. The paper is structured to consist of three parts. The first and the second parts of the paper theoretically consider the concept of collaborative economy, while the third part of the paper analyzes the presence of the sharing model at the level of the
European Union. The first part sheds light on the theoretical aspects of the collaborative economy. The second part examines the relevance and deeper significance of the collaborative economy. Finally, the third part provides an answer to the question why the collaborative economy is important for the $\mathrm{EU}$, examines various problems and obstacles to the affirmation of this new business model, and provides possible scenarios for its development in the future.

Table 1: Conceptualizing the collaborative economy

\begin{tabular}{l} 
COLLABORATIVE ECONOMY \\
\hline \multicolumn{1}{|c|}{ KEY TRAITS: } \\
1. Enabled by internet technologies. \\
2. Connecting distributed networks of people and/or assets. \\
3. Making use of the idling capacity of tangible and intangible assets. \\
4. Encouraging meaningful interactions and trust. \\
5. Embracing openness, inclusivity and the commons.
\end{tabular}

\begin{tabular}{|c|c|c|c|}
\hline \multicolumn{4}{|c|}{ KEY PILLARS: } \\
\hline $\begin{array}{l}\text { 1. Collaborative } \\
\text { consumption } \\
\text { Gaining access to goods } \\
\text { or services through } \\
\text { bartering, renting, } \\
\text { lending, trading, leasing, } \\
\text { exchanging, reselling and } \\
\text { swapping. }\end{array}$ & $\begin{array}{l}\text { 2. Collaborative } \\
\text { production } \\
\text { Groups or networks of } \\
\text { individuals collaborate to } \\
\text { design, produce or } \\
\text { distribute goods. }\end{array}$ & $\begin{array}{l}\text { 3. Collaborative } \\
\text { learning } \\
\text { Learning experiences that } \\
\text { are open to anyone and } \\
\text { where people share } \\
\text { resources and knowledge } \\
\text { to learn together. }\end{array}$ & $\begin{array}{l}\text { 4. Collaborative } \\
\text { finance } \\
\text { Funding, lending and } \\
\text { investment services offered } \\
\text { outside traditional financial } \\
\text { institutions. }\end{array}$ \\
\hline $\begin{array}{l}\text { REDISTRIBUTION } \\
\text { MARKETS } \\
\text { Reselling or } \\
\text { redistributing things } \\
\text { from where they are not } \\
\text { needed to where they are } \\
\text { wanted }\end{array}$ & $\begin{array}{l}\text { COLLABORATIVE } \\
\text { DESIGN } \\
\text { People work together to } \\
\text { design a product or } \\
\text { service. This can be } \\
\text { prompted by an open call, } \\
\text { design brief or challenge }\end{array}$ & $\begin{array}{l}\text { OPEN COURSES AND } \\
\text { COURSEWARE } \\
\text { Courses, lectures and } \\
\text { educational content freely } \\
\text { and openly available to } \\
\text { anyone }\end{array}$ & $\begin{array}{l}\text { CROWDFUNDING } \\
\text { Groups of people contribute } \\
\text { directly to a specific project's } \\
\text { funding goal }\end{array}$ \\
\hline $\begin{array}{l}\text { PRODUCT SERVICE } \\
\text { SYSTEMS } \\
\text { Paying to access goods, } \\
\text { instead of owning them } \\
\text { outright }\end{array}$ & $\begin{array}{l}\text { COLLABORATIVE } \\
\text { MAKING } \\
\text { People connect outside } \\
\text { formal institutions or } \\
\text { organizing structures to } \\
\text { collaborate on making } \\
\text { projects and products }\end{array}$ & $\begin{array}{l}\text { SKILLSHARING } \\
\text { People offer to teach or } \\
\text { share a skill they have }\end{array}$ & $\begin{array}{l}\text { SOCIAL LENDING } \\
\text { People with money to invest are } \\
\text { connected directly with people } \\
\text { looking to borrow funds }\end{array}$ \\
\hline $\begin{array}{l}\text { COLLABORATIVE } \\
\text { LIFESTYLES } \\
\text { People share and } \\
\text { exchange intangible } \\
\text { assets, such as time, } \\
\text { skills, money and space }\end{array}$ & $\begin{array}{l}\text { COLLABORATIVE } \\
\text { DISTRIBUTION } \\
\text { People organize and fulfil } \\
\text { the distribution of goods } \\
\text { directly to peers }\end{array}$ & $\begin{array}{l}\text { CROWD-SOURCED } \\
\text { KNOWLEDGE } \\
\text { People publicly aggregate } \\
\text { their knowledge or } \\
\text { collectively problem-- } \\
\text { solve }\end{array}$ & $\begin{array}{l}\text { COMPLEMENTARY } \\
\text { CURRENCIES } \\
\text { Alternatives to state-managed } \\
\text { legal tender that enable different } \\
\text { ways for groups to measure and } \\
\text { acknowledge value } \\
\text { COLLABORATIVE } \\
\text { INSURANCE } \\
\text { People band together to form } \\
\text { their own insurance pools }\end{array}$ \\
\hline
\end{tabular}

Adapted from: (Stokes et al., 2014) 
Table 2: Categories and examples of collaborative economy activities

\begin{tabular}{|c|c|c|c|}
\hline & $\begin{array}{l}\text { COLLABORATIVE } \\
\text { ECONOMY ACTIVITY }\end{array}$ & CHARACTERISTICS & COMPANIES \\
\hline \multirow{3}{*}{$\begin{array}{l}\text { THE FOR PROFIT } \\
\text { COLLABORATIVE } \\
\text { ECONOMY }\end{array}$} & Recirculation of goods & $\begin{array}{l}\text { Peer-to peer sale or resale of } \\
\text { unwanted items }\end{array}$ & $\begin{array}{l}\text { Ebay, Craigslist, Gumtree, } \\
\text { Allegro, Etsy, Poshmark, } \\
\text { collaborative food markets }\end{array}$ \\
\hline & Increase of durable assets & $\begin{array}{l}\text { Peer-to-peer renting (car } \\
\text { rental, bicycle renting, tools } \\
\text { and lodging) }\end{array}$ & $\begin{array}{l}\text { Snapgoods, municipal } \\
\text { automatized bicycle renting } \\
\text { (Veturillo in War-saw), } \\
\text { RelayRides, Liquid, Zaarly, } \\
\text { FashionHire, etc. }\end{array}$ \\
\hline & Increase of services & $\begin{array}{l}\text { Peer-to-peer services (car } \\
\text { sharing, animal sitting }\end{array}$ & $\begin{array}{l}\text { Uber, BlaBla car, Airbnb, } \\
\text { Dog Vacay, TaskRabbit }\end{array}$ \\
\hline \multirow{4}{*}{$\begin{array}{l}\text { THE NON-FOR- } \\
\text { PROFIT } \\
\text { COLLABORATIVE } \\
\text { ECONOMY }\end{array}$} & $\begin{array}{l}\text { Service and goods } \\
\text { exchange }\end{array}$ & $\begin{array}{l}\text { Local communities' services } \\
\text { exchange (I mow your lawn } \\
\text { you tutor my daughter in } \\
\text { English) }\end{array}$ & $\begin{array}{l}\text { Home swapping, clothes } \\
\text { swapping, Couchsurfing, } \\
\text { local exchange systems, Fon } \\
\text { (wifi sharing platform), } \\
\text { NeighborGoods, etc. }\end{array}$ \\
\hline & $\begin{array}{l}\text { Knowledge } \\
\text { and culture sharing }\end{array}$ & $\begin{array}{l}\text { Platforms enabling the free } \\
\text { circulation of information } \\
\text { and knowledge through } \\
\text { individuals' participation }\end{array}$ & $\begin{array}{l}\text { Wikipedia, Coursera, } \\
\text { Wikia,YouTube, Ted, Spotify }\end{array}$ \\
\hline & $\begin{array}{l}\text { Financial } \\
\text { community } \\
\text { participation }\end{array}$ & $\begin{array}{l}\text { Online platforms where } \\
\text { projects or inventions get to } \\
\text { be funded by individuals in a } \\
\text { participative manner. Also, } \\
\text { platforms of participative } \\
\text { credit }\end{array}$ & $\begin{array}{l}\text { Kickstarter, Polak Potrafi, } \\
\text { Kokos, } \\
\text { Lending Club, Kiva (micro } \\
\text { loans) }\end{array}$ \\
\hline & $\begin{array}{l}\text { Productive assets' } \\
\text { sharing }\end{array}$ & $\begin{array}{l}\text { Platform enabling } \\
\text { production rather that } \\
\text { consumption (coworking } \\
\text { spaces, workshops, etc.) }\end{array}$ & Skill share \\
\hline
\end{tabular}

Source: (Beaumont, 2016)

\section{GENERAL ABOUT COLLABORATIVE ECONOMY AS A CONCEPT AND MODERN PARADIGM - THEORETICAL FOUNDATIONS}

Collaborative economy competes with traditional ways of producing, distributing and consuming goods and services (see Table 1.). These models imply maximum utilization of scarce resources based on technological support and social capital of the community. The collaborative economy relies on the creative entrepreneurial spirit of individuals rather than on state intervention and centrally planned well-being.

The growth of the collaborative economy is stimulated by the following macroeconomic factors, namely: (1) erosion of consumer trust in the corporate world, as a direct consequence of the economic and financial crisis, making them more receptive to peer-to-peer initiatives that eliminate the power of corporates; (2) rising unemployment rates and a simultaneous decline in consumer purchasing power, which imposes the need to search for new ways to earn extra money and the same savings for your own daily needs and (3) the required technology for hosting an online peer-topeer market has, in recent years, become available at more reasonable cost. At the same time, the public is strengthening its insights into networked activities and thus expressing growing confidence in online transactions (European Union, 2013). In a collaborative economy, data becomes the primary raw material, while fixed costs are largely externalized. The key activities of the collaborative economy are shown in Table 2.

\section{COLLABORATIVE ECONOMY - BASIC CHARACTERISTICS, IMPORTANCE AND WIDER POLICY IMPLICATIONS}

Collaborative economy can be defined as an economic system that is characterized by five key characteristics, namely (Sundararajan, 2016): (1) Largely market-based: the collaborative economy generates new markets, and thus the emergence of 
new services and exchangeable goods, which ultimately affects the raising of levels of economic activity, (2) High-impact capital: collaborative economy opens new opportunities for everything, from assets and skills to time and money, to be used at levels closer to their full capacity; (3) Crowd-based "networks" rather than centralized institutions or "hierarchies": the supply of capital and labor comes from decentralized crowds of individuals rather than corporate or state aggregates; future exchange may be mediated by distributed crowd-based marketplaces rather than by centralized third parties; (4) Blurring lines between the personal and the professional: the supply of labor and services often commercializes and scales peer-to-peer activities like giving someone a ride or lending someone money, activities that used to be considered "personal" and (5) Blurring lines between fully employed and casual labor, between independent and dependent employment, between work and leisure: many traditionally full-time jobs are supplanted by contract work that features a continuum of levels of time commitment, granularity, economic dependence, and entrepreneurship.

Collaborative economy activities fall into four broad categories: 1 . Sharing of productive assets, 2. Increased utilization of durable assets, 3. Recirculation of goods and 4. Exchange of services (EY, 2015). This type of economy rests on three basic principles, namely (Chloe, 2018): (1) to tap into the idle capacity of private, underutilized goods - encouraging maximum resource efficiency (and sharing of private goods is one of the key aspects in this regard), the key role of the collaborative economy is in reducing excessive consumption; (2) to facilitate sharing among strangers building trust - in order for users to feel safe and confident, the collaborative economy must serve to foster social trust in each other and thus strengthen a sense of shared responsibility and (3) to develop a critical mass - in order for a collaborative economy to function successfully requires a critical mass of a certain number of actors - buyers, sellers, renters or lenders. Strong public support is of paramount importance, especially as this economy continues to grow, especially since the fact must be taken into account that the lack of regulation of this decentralized economy may hinder further expansion and valorization of its full potential.
Despite the undoubted shortcomings, an increasing number of individuals are choosing to actively participate in the sharing economy for economic, social and environmental reasons. The main advantages of the sharing economy enabled by digital transformation and the development of disruptive technologies relate to (Stojković, 2019): (1) Favorable prices - they are possible because of the cost-effectiveness of the services they use, information to combine supply and demand in a way that makes better use of resources; (2) Environmental sustainability - because the demand for new goods or the construction of new facilities decreases; (3) Belonging to the community sharing platforms make it easier to share between people who do not know each other and who do not have mutual friends or some other link; (4) Possibility of additional income - individuals who want to increase their fixed income have the opportunity to provide services from time to time using sharing economy platforms, while those who do not like normal working time schedules have the opportunity to work according to their own conditions and schedule. Also, the sharing economy provides the opportunity to earn extra money for retirees, people with disabilities or health problems: (5) Use of unused capacities and encourage new consumption - the use of their own property, whether real estate or movables, allows individuals to rent otherwise unused property or that has not been used entirely to earn additional income. Providing consumers with access to services that were previously unavailable or less convenient to them, the sharing economy can access untapped markets and increase overall consumption; (6) Better consumer experience The innovations offered by the sharing economy could significantly reduce the uncomfortable aspects of transactions while increasing consumer welfare. Individuals with insufficiently used goods can be connected via the app to other users who need exactly that kind of goods enabling the delivery of an efficient service at a low price and of high quality and (7) Creating trust between the user and the service provider - The sharing economy allows for a certain level of trust between consumers and service providers. The importance of the collaborative economy is also evidenced by its importance in contributing to the realization of the Sustainable Development Goals (SDGs), as shown in Table 3. 
Table 3: The collaborative economy contribution to the SDGs

\begin{tabular}{|c|c|}
\hline Sustainable Development Goal & SE Contributions \\
\hline SDG 1. No poverty. & $\begin{array}{l}\text { Allowing users to earn extra income. } \\
\text { The opportunity for self-employment. } \\
\text { Enabling previously marginalized collectives to gain another source of } \\
\text { income. }\end{array}$ \\
\hline SDG 2. Zero hunger. & $\begin{array}{l}\text { P2P redistribution of food surplus. } \\
\text { Sharing of urban gardens. } \\
\text { Granting access to underused land. } \\
\text { Reducing food waste. }\end{array}$ \\
\hline $\begin{array}{l}\text { SDG 3. Good health and well- } \\
\text { being. }\end{array}$ & Allowing people to connect with likeminded others. \\
\hline SDG 4. Quality education. & $\begin{array}{l}\text { Facilitating access to knowledge and educational resources through } \\
\text { platforms. }\end{array}$ \\
\hline SDG 5. Gender equality. & $\begin{array}{l}\text { Providing better employment opportunities for marginalized communities. } \\
\text { Equal opportunities. }\end{array}$ \\
\hline $\begin{array}{l}\text { SDG 7. Affordable and clean } \\
\text { energy. }\end{array}$ & $\begin{array}{l}\text { Creating renewable energy networks. } \\
\text { Connecting people in need of energy and those willing to share theirs. }\end{array}$ \\
\hline $\begin{array}{l}\text { SDG } 8 \text {. Decent work and economic } \\
\text { growth. }\end{array}$ & $\begin{array}{l}\text { Promoting inclusive and sustainable economic growth. } \\
\text { Providing employment opportunities for all users. } \\
\text { Reducing barriers to entrepreneurship. }\end{array}$ \\
\hline $\begin{array}{l}\text { SDG 9. Industry, innovation, and } \\
\text { infrastructures. }\end{array}$ & $\begin{array}{l}\text { Fostering responsible innovation. } \\
\text { Increasing customer awareness regarding sustainable solutions. }\end{array}$ \\
\hline SDG 10. Reduced inequalities. & $\begin{array}{l}\text { Allowing owners of goods to benefit from extra income. } \\
\text { Allowing users to access goods without acquiring them. } \\
\text { Offering equal opportunities to all kinds of users, without discrimination } \\
\text { on basis of sex, race or level of income. }\end{array}$ \\
\hline $\begin{array}{l}\text { SDG } 11 . \text { Sustainable cities and } \\
\text { communities. }\end{array}$ & $\begin{array}{l}\text { Enhancing mobility. } \\
\text { Reducing the negative environmental impact. } \\
\text { Reducing personal vehicle ownership. }\end{array}$ \\
\hline $\begin{array}{l}\text { SDG } 12 . \text { Responsible consumption } \\
\text { and production. }\end{array}$ & $\begin{array}{l}\text { Supporting a more sustainable consumption model. } \\
\text { Actively fostering the maximum use of resources. } \\
\text { Reducing the number of resources required. } \\
\text { Facilitating access to goods, rather than promoting their ownership. }\end{array}$ \\
\hline SDG 13. Climate action. & $\begin{array}{l}\text { Promoting a more rational approach to consumption. } \\
\text { Reducing pollution. }\end{array}$ \\
\hline $\begin{array}{l}\text { SDG 16. Peace, justice, and strong } \\
\text { institutions. }\end{array}$ & $\begin{array}{l}\text { Creating communities that favor interactions among users. } \\
\text { Forging trust and social understanding. }\end{array}$ \\
\hline
\end{tabular}

\section{COLLABORATIVE ECONOMY AS AN ORIENTATION OF THE EUROPEAN UNION - STATUS, TRENDS AND LIMITS}

Models of the sharing economy lead to new economic and social interactions within all members of the European Union and across Europe as a whole. In order to promote the balanced development of the collaborative economy and its better exploitation by citizens, businesses and countries under the auspices of the $\mathrm{EU}$, the European Agenda for the Collaborative Economy adopted in 2016 is essential (COM, 2016), which clearly provides the rules of the game and key policy recommendations in this areas. The most important regulatory areas of the collaborative economy covered by the mentioned agenda are: market access requirements, consumer protection, employment and taxation. The Agenda also recognizes the economic and social importance of the collaborative economy in terms of contribution to generating economic growth, new employment and raising competitiveness, and expanding aggregate supply and reducing price levels.

\section{Development status, generated values and empirical findings}

In order to look at the attitudes, perceptions and practice of Europeans towards the collaborative economy, we will use the Eurobarometer survey on the collaborative economy published by the European Commission in April 2018 as the second 
survey (European Commission, 2018), while the first was published in 2016. Among others, according to mentioned survey the most frequently used via collaborative platforms are services in the accommodation (57\% among respondents who have used this services) and transport sectors (51\%) (for detail see Table 4.).

\section{Table 4: Using a service offered via a} collaborative platform across sectors

\begin{tabular}{|c|c|}
\hline Accommodation (e. g. renting an apartment) & 57 \\
\hline Transport (e. g. car sharing) & 51 \\
\hline $\begin{array}{l}\text { Food-related services (e. g. home delivery, } \\
\text { food sharing) }\end{array}$ & 33 \\
\hline $\begin{array}{l}\text { Household services (e. g. gardening, repairs, } \\
\text { child care) }\end{array}$ & 14 \\
\hline $\begin{array}{llll}\begin{array}{l}\text { Professional services (e. g. IT services, } \\
\text { accounting) }\end{array} & & & \\
\end{array}$ & 9 \\
\hline $\begin{array}{l}\text { Collaborative finance (e. g. peer-to-peer } \\
\text { lending or crowd-funding) }\end{array}$ & 8 \\
\hline Other & 6 \\
\hline \multicolumn{2}{|c|}{$\begin{array}{l}\text { Note: Q In which of the following sectors have you used a } \\
\text { service offered via a collaborative platform? (MULTIPLE } \\
\text { ANSWERS POSSIBLE) (\% - EU). } \\
\text { Base: respondents who have used services offered via } \\
\text { collaborative platforms (n=6,389) } \\
\text { Source: (European Commission, 2018) }\end{array}$} \\
\hline
\end{tabular}

When it comes to highlighting the key benefits of using a collaborative platform, there are significant differences in the proportions of users. So, nearly three quarters $(73 \%)$ of those who have used services offered via a collaborative platform say that a more convenient access to services is an advantage of such platforms compared with traditional channels. Only $2 \%$ say that there are no advantages of collaborative platforms over traditional channels. Small proportions spontaneously mention other advantages or say they don't know (both 1\%) (for detail see Table 5.).

On the other hand, the most frequently mentioned disadvantage is the lack of clarity about who is responsible in the event of a problem (49\%), followed by misleading ratings and reviews (38\%), misuse of personal data (37\%), and less trust in the providers of services offered via collaborative platforms (34\%). More than one fifth of the users mention as a disadvantage the two following issues: services offered via collaborative platforms are not as expected (24\%), or that there are problems with the online booking process or payments (22\%) (see: Table 6.).
Table 5: Advantages of using collaborative platforms in comparison with traditional channels

\begin{tabular}{|l|l|}
\hline A more convenient access to services & 73 \\
\hline $\begin{array}{l}\text { The availability of ratings and reviews by } \\
\text { users }\end{array}$ & 60 \\
\hline $\begin{array}{l}\text { Cheaper or free services offered via } \\
\text { collaborative platforms }\end{array}$ & 59 \\
\hline $\begin{array}{l}\text { A wider choice of services unavailable via } \\
\text { traditional channels }\end{array}$ & 56 \\
\hline $\begin{array}{l}\text { The opportunities they offer to interact with } \\
\text { interesting people }\end{array}$ & 34 \\
\hline $\begin{array}{l}\text { Possibility of exchanging services instead of } \\
\text { paying for them }\end{array}$ & 31 \\
\hline None, there are no advantages & 2 \\
\hline Other & 1 \\
\hline
\end{tabular}

Note: Q In your personal experience, what are the advantages of using collaborative platforms compared with traditional channels, if any? (MULTIPLE ANSWERS POSSIBLE) (\% $\mathrm{EU})$.

Base: respondents who have used services offered via collaborative platforms $(n=6,389)$

Source: (European Commission, 2018)

Table 6: Disadvantages of using collaborative platforms in comparison with traditional channels

\begin{tabular}{|l|l|}
\hline $\begin{array}{l}\text { Lack of clarity about who is responsible in } \\
\text { the event of a problem }\end{array}$ & 49 \\
\hline Misleading ratings and reviews from users & 38 \\
\hline Misuse of your personal data & 37 \\
\hline $\begin{array}{l}\text { Less trust in the providers of services } \\
\text { offered via collaborative platforms }\end{array}$ & 34 \\
\hline $\begin{array}{l}\text { Services offered via collaborative platforms } \\
\text { are not as expected }\end{array}$ & 24 \\
\hline $\begin{array}{l}\text { Problems with the online booking process } \\
\text { or payments }\end{array}$ & 22 \\
\hline None, there are no significant issues & 15 \\
\hline Other & 3 \\
\hline
\end{tabular}

Note: Q In your personal experience, what are the disadvantages of using collaborative platforms compared with traditional channels, if any? (MULTIPLE ANSWERS POSSIBLE) (\%-EU).

Base: respondents who have used services offered via collaborative platforms $(n=6,389)$

Source: (European Commission, 2018)

Regarding the main reasons for offering services via collaborative platforms, just over half say that these platforms offer an easy way to interact with consumers $(53 \%)$ and a more sustainable and efficient use of available assets (51\%), while half say that they give access to more consumers (50\%) and represent an additional source of income $(50 \%)$. Very few (2\%) spontaneously mention other reasons for offering services via collaborative platforms, while $6 \%$ do not identify any specific reasons for using these platforms to offer services (see Table 7.). 
Table 7: Reasons for offering services via collaborative platforms

\begin{tabular}{|l|l|}
\hline An easy way to interact with consumers & 53 \\
\hline $\begin{array}{l}\text { More sustainable and efficient use of } \\
\text { available assets }\end{array}$ & 51 \\
\hline Access to more consumers & 50 \\
\hline An additional source of income & 50 \\
\hline $\begin{array}{l}\text { An easy opportunity to become a services } \\
\text { provider }\end{array}$ & 43 \\
\hline Flexible working hours & 40 \\
\hline $\begin{array}{l}\text { An opportunity to offer additional or more } \\
\text { innovative services }\end{array}$ & 36 \\
\hline Main source of income & 10 \\
\hline None & 6 \\
\hline Other & 2 \\
\hline
\end{tabular}

Note: Q For which of the following reasons you offer services via collaborative platforms? (MULTIPLE ANSWERS POSSIBLE) (\% - EU).

Base: respondents who have offered services via collaborative platforms $(n=1,598)$

Source: (European Commission, 2018)

In 2018 (the last available), the European Commission published two interesting studies that examine in detail the current level of economic development of the collaborative economy in the European Union, as well as at the sector level, based on data collected for a total of 651 collaborative platforms in the time interval between March and December 2017, from the 28 Member States (Austria, Belgium, Bulgaria, Cyprus, Czech Republic, Germany, Denmark, Estonia, Greece, Spain, Finland, France, Croatia, Hungary, Ireland, Italy, Lithuania, Luxembourg,
Latvia, Malta, Netherlands, Poland, Portugal, Romania, Sweden, Slovenia, Slovakia, United Kingdom) (for detail see: European Union, 2018a; 2018b). Assessment of economic effects of a collaborative economy at the EU level can be done by looking at three key indicators: 1. revenue, 2 . employment and 3. the number of platforms (for details see Table 8.). In the EU-28 in 2016 the overall market size of the collaborative economy was estimated to be EUR 26.5 billion, which is $0.17 \%$ of total EU-28 GDP. The highest level of revenue is generated by the financial sector (EUR 9.6 billion), and the smallest by the transport sector (EUR 4 billion). In terms of employment, across the EU the collaborative economy generates approximately 394,000 jobs, which is $0.15 \%$ of total EU-28 employment. The largest number of employees is related to the transport sector $(124,800$ persons employed). In all observed sectors, there is a total of 651 platforms identified as collaborative domestic platforms, of which approximately $95 \%$ of collaborative platforms are for-profit - their transactions are reward based. The analysis of the economic performance of the collaborative economy at the EU level points to the general conclusion that there is a significant untapped market potential in this area, although this business model can, in changing conditions of demand in the labor market and products, certainly strengthen the resilience of the entire EU economy generating alternative employment and income opportunities.

Table 8: Estimated collaborative economy according to key indicators in the EU-28 by sectors

\begin{tabular}{|l|l|c|c|c|}
\hline & \multicolumn{1}{|c|}{ Transport } & Accommodation & Finance & Online skills \\
\hline Revenue (2016) & 4 (EUR billion) & $7.3 \mathrm{~B}$ & $9.6 \mathrm{~B}$ & $5.6 \mathrm{~B}$ \\
\hline Employment (2016) & 124 800 number of persons & 113300 & 67300 & 89500 \\
\hline $\begin{array}{l}\text { Number of platforms } \\
(2017)\end{array}$ & $\begin{array}{l}\text { 142 domestic collaborative } \\
\text { economy for-profit platforms }\end{array}$ & 62 & 268 & 179 \\
\hline
\end{tabular}

Adapted from: (European Union, 2018a)

Observed by individual countries, France is the country with the largest market for the collaborative economy in 2016, which is estimated at EUR 6.5603 billion, making $25 \%$ of the total collaborative EU-28 market. What is striking is the fact that 7 largest markets of the collaborative economy (in addition to the mentioned France, there are also the UK, Poland, Spain, Germany, Italy and Denmark) account for $80 \%$ of total collaborative revenues in the EU-28 in 2016. What is even more interesting for our analysis is the fact that countries performing above average typically have more than one collaborative economy sector that was above the EU-28 average (France, Latvia, Luxembourg, Czech Republic and Poland have two, whereas Estonia and Slovakia have three above average collaborative economy sectors, but although the Netherlands only has one, it shows average development in all three of its other collaborative economy sectors) (Table 9.). Greece and Latvia also exhibited above average performance in two sectors, which explains the higher number of persons employed compared to other countries in the below average group. Finally, the sectoral analysis of the collaborative economy reflects national economic specialization 
to a good extent. For example, the strong transport online skills in Spain and Slovakia, sector in the UK, the finance sector in Sweden, accommodation in Cyprus, etc.

Table 9: Performance of collaborative economy at sector level in Member States (\% in sectoral GDP, 2016)

\begin{tabular}{|c|c|c|c|c|}
\hline Country & Transport & Accommodation & Finance & $\begin{array}{c}\text { Online } \\
\text { skills }\end{array}$ \\
\hline AT & 0.005 & 0.988 & 0.027 & 0.001 \\
\hline BE & $0 ., 035$ & 0.248 & 0.003 & 0 \\
\hline BG & 0.006 & 2.941 & 0.006 & 0.003 \\
\hline $\mathbf{C Y}$ & 0 & 1.135 & 0 & 0 \\
\hline $\mathrm{CZ}$ & 0.021 & 1.539 & 0.135 & 0.002 \\
\hline DE & 0.005 & 0.439 & 0.019 & 0.001 \\
\hline DK & 0.015 & 0.448 & 0.007 & 0.002 \\
\hline $\mathbf{E E}$ & 0.117 & 0.443 & 0.219 & 0.035 \\
\hline EL & 0.033 & 0.759 & 0 & 0.024 \\
\hline ES & 0.013 & 0.712 & 0.017 & 0.020 \\
\hline FI & 0.024 & 2.444 & 0.020 & 0.001 \\
\hline FR & 0.061 & 0.718 & 0.038 & 0.009 \\
\hline HR & 0.030 & $0 . .898$ & 0.001 & 0 \\
\hline HU & 0.019 & 0.891 & 0 & 0.001 \\
\hline IE* $^{*}$ & 0.015 & - & 0.004 & 0 \\
\hline IT & 0.006 & 0.338 & 0.009 & 0.001 \\
\hline LT & 0.037 & 0.887 & 0.014 & 0 \\
\hline LU* & 0.001 & - & 0 & 0.019 \\
\hline $\mathbf{L V}$ & 0.032 & 0.370 & 0.176 & 0 \\
\hline MT & 0.037 & - & 0 & 0 \\
\hline NL & 0.039 & 0.309 & .008 & 0.002 \\
\hline PL & 0.027 & 0.267 & 0.023 & 0.145 \\
\hline PT & 0.031 & 0.720 & 0.012 & 0.005 \\
\hline RO & 0.028 & 0.505 & 0.004 & 0 \\
\hline SE & 0.005 & 0.579 & 0.093 & 0 \\
\hline SI & 0 & 1.579 & 0.001 & 0 \\
\hline SK & 0.039 & 1.044 & 0.012 & 0.013 \\
\hline UK & 0.064 & 0.345 & 0.019 & 0.001 \\
\hline EU-28 average & 0.026 & 0.830 & 0.031 & 0.010 \\
\hline
\end{tabular}

\section{Regulatory challenges, COVID-19 and look into the future}

The key problems in the context of regulation when it comes to the EU concern regulatory differentiation and lack of regulatory clarity, where existing legislation may not cover certain activities and transactions, or where legislation developed for conventional industries is incorrectly applied to markets in the collaborative economy. Very complex and often legally contradictory regulations related to the collaborative economy further fragment the digital single market. In order to establish a constructive regulatory framework at the EU level, the following recommendations need to be taken into account (Darcy, \& Chris, 2014):
1. Encourage bottom-up, organic, self-regulation rather than top-down, rigid government control - bottom-up governance tends to be a dynamic, nimble, flexible and cost-effective solution, which is mostly achieved through use of rating and reputation systems.

2. Reduce occupational licensing - in order to avoid discouraging the emergence of new technologies and service creation and establishing inefficient business practices. Reducing economy-wide occupational licensing will promote efficiency and experimentation, and is a precondition for sharing economy models to deliver their potential benefits.

3. Reduce industry specific controls that entrench business structure - thus avoiding the closure of 
future potential industries, business models or technologies.

4. Provide an environment for platforms to develop private solutions - regulators should create an environment that allows development of new and more efficient contracting regimes to further improve their business models.

5. Reduce regulations to encourage entrepreneurship and flexible work practices - refers to encouraging entrepreneurship, innovation and emerging industries through deregulation of labor markets. Given the high level of experimentation within the collaborative economy, in order to maximize its positive effects, it is necessary to ensure that financial markets, labor markets and contract laws be adaptable and flexible.

The current pandemic (COVID-19) is also an opportunity to reconsider the European Union's approach to the collaborative economy (for one possible solution see Table 10.).

Table 10: Framework for reviewing the EU's collaborative economy in the context of the global COVID-19 pandemic

\begin{tabular}{|l|l|}
\hline \multicolumn{1}{|c|}{ (Potential) impact } & \multicolumn{1}{c|}{ Opportunity for the EU } \\
\hline Heightened digital divide & $\begin{array}{r}\text { Foster investment in the networks of high capacity necessary to } \\
\text { provide e-commerce services }\end{array}$ \\
$-\begin{array}{l}\text { Reinforce EU universal service and social inclusion policies to bridge } \\
\text { the digital divide both within the EU and across the Member States }\end{array}$ \\
\hline $\begin{array}{l}\text { Exposure of limited platform } \\
\text { worker protection }\end{array}$ & $\begin{array}{l}\text { Reflect on ways to strengthen platform workers' social rights } \\
\text { Clarify the situation of self-employed individuals providing services } \\
\text { through platforms }\end{array}$ \\
\hline $\begin{array}{l}\text { Increased consumer protection } \\
\text { issues in the online environment } \\
\text { (such as unreasonable price } \\
\text { increases and product safety) }\end{array}$ & $-\begin{array}{l}\text { Reinforce product safety rules and consumer protection standards in } \\
\text { the e-commerce space }\end{array}$ \\
\hline Increased cybersecurity threats & $-\begin{array}{l}\text { Promote more transparency in the online environment } \\
\text { Strengthen the security and infrastructure resilience of online activities }\end{array}$ \\
\hline $\begin{array}{l}\text { Highlighted need for } \\
\text { international rules on e- } \\
\text { commerce }\end{array}$ & $\begin{array}{l}\text { Foster enactment of international common rules on e-commerce } \\
-\end{array}$ \\
\hline
\end{tabular}
Source: (Bassot, 2020)

The following are possible exploratory scenarios for the future development of the EU's collaborative economy by 2030 (Bock et al., 2016):

\section{1) SCENARIO I}

A pervasive self-organizing collaborative ethos in a largely conventional economic context, with a surge in local initiatives

Community-owned/cooperative platforms shape the collaborative economy, emphasizing transparency and self-regulation

Such a scenario may be the result of further strengthening of the civil sector, an increasing share of bottom-up, community-based approaches and incorporation of elements of direct democracy. The basic motto is Think Global - Act Local, while ownership loses on importance. Economic development will be determined by fairness, openness and transparency, while reputation, trust and corporate social responsibility are key to business success. There is a huge number of strong not-for-profit, community-owned platforms and cooperatives. Social protection rules have been adapted to provide security and to cater for the diversity of income generation and employment schemes. Minimum requirements were set regarding a minimum remuneration per hour, quality of work, transparency, profile portability, liability, etc. The problem in such a scenario may be fragmented and unstable decision making.

\section{2) SCENARIO II}

Public authorities push for the optimum use of resources and investment in labor and expertise to build a sustainable future

A clear legal framework provides the boundaries for an EU-centered collaborative economy with active government involvement

There is a high degree of solidarity and responsibility among citizens within the EU in achieving what is called a fair, resilient and green EU. Production patterns and consumption patterns take on a local character. Access over ownership of goods is an established way of cutting costs of 
product use or spreading costs over a longer time period. Local sales, exchanges or rentals of goods and services are facilitated by complementing the state-owned platform with specialized, for-profit platforms at EU or local level. Private owners of goods rather rent than lend these goods with the aim of sharing part of the high acquisition costs. An EU quality label has been developed, and only platforms with this label have market access and are eligible for any public support. Governments and public bodies are active users of platforms for provision of access to state-owned assets, for provision of public services or for support to other activities. Digital labor market platforms are almost the only source of income for a growing number of workers. Furthermore, labor laws have been adapted to better cater for the different types of work relations, ensuring appropriate security and rights for workers while not inhibiting further development of collaborative platforms. A significant number of people will be influenced by online work via platforms as well as telework to leave cities and go to villages to reduce the cost of living as a result of cheaper domestic food and housing.

\section{3) SCENARIO III}

EU governance pushes for unfettered market access and technology as a way towards a more resource efficient future

A large variety of commercial platforms thrive in global competition and in an increasingly polarized, micro-entrepreneur society

The emphasis is on strengthening global competitiveness and the functionality of the internal market, which will be achieved through an adequate regulatory and policy framework creating business-friendly, lean EU-level governance. There is a trend of privatization (as well as modernization) of public services due to huge pressures to reduce public spending, as a result of which the guarantee of social schemes is only available as a last resort, so citizens are recommended to use private insurance schemes. An additional further liberalization of labor law increased the flexibility for employers to hire and lay off employees and thus made reactions to changing economic conditions easier. Rise of cost of living as a consequence of prescribing higher taxes on the use of resources has led to an escalation of social inequalities. Previously, it would lead to high savings rates, strong investment in research and development, and the achievement of a technologically advanced industrial environment in the EU. In a situation with limited social security provisions, ownership maintains its strong value. As products become more expensive, quality and product lifetime are more important. Financing of acquisitions and maintenance is aging through product rental with the help of several consolidated large digital platforms. The polarization of society into those that own (and rent) and those that can only afford access from time to time grows. Goods produced in the EU are recording a growing market share in the world as a result of the application of advanced technologies, which further entails that maintenance services generate additional jobs and open space for installing new business models - to provide services with the products instead of only the products. Unemployment has been reduced by making employment cheaper and by further development of a strong service sector. Growing demand for care that cannot be fulfilled by limited public services opened up new business opportunities for platforms, partially merging with traditional providers.

\section{4) SCENARIO IV}

Weak governance combined with corporate power puts pressure on citizens to find diverse ways to ensure livelihood

Large, commercial platforms dominate the collaborative economy in a highly competitive environment, affected by lack of trust

It starts from the assumption that the EU and its member states are modest players on the global market and the international scene in general, which is a direct consequence of the mix of poor governance at the EU and national levels, political fragmentation and economic stagnation. In relation to the above, the influence of multinational companies on policy-making has become important, which is a consequence of limited public budgets and high unemployment rates. There is a lack of political capital for more decisive reform efforts, and economic shortsightedness prevails in the long-term strategic approach and social and environmental concerns. There is a social stratification of the rich European elite, which provides itself with high-quality services (primarily education) and the former middle class, which records a drastic reduction in income and begins to fight for life. Social cohesion has broken down and solidarity has given way to a dog-eat-dog, competitive society, which, as a result, has constant conflicts and unrest. There is a 
general distrust in the society towards business and institutions, as well as among the citizens within the EU. As income security declines and social security is largely left to individual, private initiative and corporate- or charity-based approaches, ownership and property become essential as an asset to generate and secure supplementary income. In this environment, the once diverse landscape of different business models using digital platforms has given way to a dominance of few, large platforms, which belong to multinational corporations. Advanced digitalization and maximum outsourcing of tasks by companies via platforms leads to globalized competition in the labor market and a strong pressure on remuneration in the EU. Only the best performers have bargaining power either towards the companies employing them or towards the platforms in terms of benefits and training. For all others "take it or leave it" is the rule and exclusion from the platforms is a real threat. Although they are now in the form of alternative, local informal urban economies, there is a significant marginalization of non-commercial collaborative platforms. Neighborhoods are starting to organize local initiatives including, e. g. the organization of social services to make up for an increasingly failing state.

In the coming period for policy makers at the national and the EU levels, when it comes to a strong step forward in the field of collaborative economy, the following recommendations are important (CEPS, 2020): (1) it is first necessary to strengthen the rules across Europe in the New Law on Digital Services, which will force collaborative platforms to take on additional responsibilities both for customer activities and for the activities of their employees; (2) for activities about which they know little (such as their users respecting specific local transport or accommodation laws or whether their users have paid the correct amount of tax) platforms should not be obliged and forced to take additional responsibility and whether they implement a policy of constant supervision; (3) it is necessary to increase the allocations for social protection for workers employed under the auspices of the collaborative economy; (4) a Good Samaritan clause is needed: collaborative economy platforms should be able to provide additional services to their workers and customers without any increase of their liability; (5) platforms should be able to continue to benefit from the country of origin principle that allows them to follow the laws of the country where they are established; (6) Digital gatekeepers do not dominate the collaborative economy because it is a competitive environment. It further means that both workers and consumers enjoy choice and can order a ride or rent short-term lodging from a different platform with a couple of keyboard clicks and (7) the collaborative economy requires sector-specific reforms, such as tax reforms.

When it comes to the future of the European collaborative economy, the answer to the following questions is critical for policy makers (Andreotti et al., 2020): (1) Foster Internet skills where policy makers should: 1 . continuously promote actions leading to further digital literacy of hard-to-target groups, 2. show increased responsibility for the growth of inequalities in the digital domain and 3. take into account the fact that in addition to technical expertise parts are internet skills and capacity to understand online reviews and reputation mechanisms, awareness of social media algorithms, and the ability to successfully manage one's own digital identity and reputation; (2) Seize opportunities for rural development: as collaborative economies are predominantly an urban phenomenon, rural areas are largely dominated by more reciprocity-based and less commercialized forms of sharing, which is a consequence of lower population density where people know each other better. Although the previous findings may lead to the conclusion that the collaborative economy is not important for rural areas, the counter-arguments are: 1. diversity and intensity of sharing could be increased if there were more transparency regarding those goods community members are actually willing to share, which would lead to a saving of scarce resources; 2. the creation of additional investment and spending in rural communities may be a consequence of expansion of well-established collaborative platforms from urban centers to rural areas and 3. as one of the basic features of rural areas is less coverage by public services, this gap can be filled simplifying the exchange of available goods and services, and thus raise the level of quality of life in these areas; (3) Share locally: as large, international services predominate within the collaborative economy, there is little representation of local alternatives that policy makers should also take into account. "One size fits all" cannot certainly be the best approach in regulation if we take into account the diametrical diversity of large platforms and local niches; (4) Consider non- 
commercial sharing: relevant actors within the collaborative economy are social enterprises (nonprofit), cooperatives, and local enterprises, whose activities policy makers must maximally support and encourage; (5) Account for professional sharing: policy makers need to find an answer to how to categorize and support providers without obstructing the opportunities provided by the sharing economy.

\section{CONCLUSION}

In recent years, the collaborative economy became a buzz word in public discourse as to the rapid pace of innovation and disruption digital collaborative economy platforms have introduced in many services markets. Collaborative economy or "sharing" economy is today a widespread economic system in which property and services are shared between private individuals, through an Internet platform and/or mobile application. The collaborative economy could create new and positive opportunities for businesses, citizens, consumers and for the economy.

The European Union has recognized the importance of the sharing economy and its impact on economic development. However, both at EU level and by the Member States, the economic contribution of the collaborative economy remains very modest, with $\%$ generally below $1 \%$ in terms of key employment and income parameters (except in the case of the accommodation sector) and that there is a significant untapped market potential in this area. In order for the collaborative economy to contribute to strengthening the resilience of the overall EU economy it would be useful to consider the following measures (Goudin, 2016): 1. Defining digital platforms - it concerns the establishment of precise criteria for identifying whether digital platforms, from a legal point of view, are industry-specific businesses or information society services; 2 . Mitigating "social exclusion" - Possible options in addressing this issue are the following alternatives: (a) tolerating a degree of social exclusion (laissez faire approach), (b) establishing a right to a reputational Year Zero, (c) regulating reputational scoring so that only socially desirable exclusions occur and (d) creating community platforms where reputation can be rebuilt; 3 . Dealing with the potential market power of the sharing economy platforms - as it is impossible for all platforms of the collaborative economy to develop a dominant position, it is essential to ensure healthy dynamics of digital markets through competition rules. In connection with the above, monopolistic tendencies in this area should be prevented, which would include the following: (a) relying upon market forces and innovation to undermine market power; (b) developing the Single Market so as to maximize the size of the market, creating the greatest scope for multiple platforms; (c) using existing competition rules to identify instances of market power and specific appropriate interventions and (d) treating sharing economy platforms in a manner analogous to regulated utilities; 4. Applying labor market regulation to sharing economy platforms - an adequate answer to the question of whether providers should be considered employees of platforms is crucial here, and possible options are: (a) mandates that all sharing economy service providers are platform employees, (b) create a new employment status of "sharing economy service provider", (c) avoid extensive roles for employers in public welfare provision, (d) encourage or facilitate platforms in developing their own user benefits and (e) extend insurance and other financial markets and 5 . Intellectual property rules: ongoing reform might need to take account of the increased importance of a cross-border hiring model, which may render geo-blocking and related restrictions superfluous.

Precisely because of the potential that the sharing economy has for strengthening solidarity among citizens, revitalizing the local economy, creating jobs, streamlining household consumption through the use of common goods, and encouraging more responsible and sustainable consumption, the European Union aims to adopt measures to encourage all member states to establish uniform regulation of the sharing economy. The main goal of adoption of new regulations for this area is to guarantee workers' rights, data protection and privacy of stakeholders, as well as to prevent monopolies and any other practices that distort competition. The sharing economy has two very different faces. One is a neoliberal brand on steroids, the other is just a continuation of healthy solidarity behavior existing since and society. Therefore, when it comes to the EU, it is necessary to continue in that direction, define and regulate, educate and encourage innovation in order to get a new sustainable economic system, stable jobs and stronger community integration from the "collaborative economy". It is crucial to demand equality in market competition and fair business 
for all. In order to encourage the wider development of the collaborative economy, the EU must, among other things, show openness to proactively embrace new innovative solutions; ensure fair working conditions and adequate social and consumer protection; and support Member States in the consistent application of appropriate legal solutions in the EU single market. At the EU level, the collaborative economy is still creating tensions between the new service providers and the existing, more traditional market operators. The main obstacle to further growth and business development of this model is regulatory divergence and market fragmentation in the digital field. In the conditions of COVID-19 pandemic, especially the collaborative economy, which grew strongly before the outbreak of the health crisis, requires a whole arsenal of measures in order to stay on the path of sustainable European growth and strong recovery. This is so in view of the fact that with the coming global economic crisis, many sectors within the collaborative economy are under strong pressure such as simple tasks and renting stuff, home rental and design and crafting; on the other hand, vital sectors are expected to remain at least at the same level or even grow primarily in the domain of software-based services, as well as banking and investment services.

\section{REFERENCES}

Andreotti, A., Anselmi, G., Eichhorn, T.H., Hoffmann, C.P, Jürss, S., \& Micheli, M. (2020).

Recommendations for the Sharing Economy: Increasing Participation. Report from the EU H2020 Research Project Ps2Share: Participation, Privacy, and Power in the Sharing Economy.

Bassot, É. (2020). Ten opportunities for Europe postcoronavirus, Exploring potential for progress in EU policy-making. In-depth analysis, EPRS - European Parliamentary Research Service, Members' Research Service. PE 652.035. ISBN 978-92-846-6954-7. https://doi.org/10.2861/254974

Bergh, A., Funcke, A., \& Wernberg, J. (2021). The Sharing Economy: Definition, Measurement and its Relationship to Capitalism. Research Institute of Industrial Economics, IFN Working Paper No. 1380.

Bock, A.K., Bontoux, L., Figueiredo do Nascimento, S., \& Szczepanikova, A. (2016). The future of the EU collaborative economy - Using scenarios to explore future implications for employment. JRC Science for policy report. ISBN 978-92-79-46977-0. https://doi.org/10.2760/354417

Botsman, R., \& Rogers, R. (2010). What's mine is yours: The rise of collaborative consumption. Harper Collins.
Bradley, K., \& Pargman, D. (2017). The Sharing Economy as the Commons of the 21st Century. Cambridge Journal of Regions, Economy and Society, 10(2), 231-47. https://doi.org/10.1093/cjres/rsx001

Beaumont, K. (2016). The Collaborative Economy in Poland and Europe: A Tool for Boosting Female Employment? CASE Working Papers, 2(126).

Centre for European Policy Studies - CEPS (2020). Europe's Collaborative Economy Charting a constructive path forward. CEPS Task Force Report Rapporteur: William Echikson, Research and Organisation Jesse Goldberg, Brussels.

Chloe, A. (2018). An Assessment of the Sharing Economy and Its Policy Solutions Through the Lens of Sustainability. Pomona, Senior Theses. 189. http://scholarship .claremont.edu/pomona_theses/189.

Codagnone, C., \& Bertin, M. (2016). Scoping the Sharing Economy: Origins, Definitions, Impact and Regulatory Issues. Institute for Prospective Technological Studies Digital Economy Working Paper 2016/01. JRC100369.

COM (2016). A European agenda for the collaborative economy. Communication from the Commission to the European Parliament, the Council, the European Economic and Social Committee and the Committee of the Regions. https://eur-lex.europa.eu/legalcontent/EN/ALL/?uri=CELEX:52016DC0356

Darcy, A., \& Chris, B., (2014 December). The sharing economy - How over-regulation could destroy an economic revolution. Institute of Public Affairs, https://www.ipa.org.au

European Commission (2018). Flash Eurobarometer 467 (The Use of Collaborative Economy). GESIS Data Archive, Cologne. Brussels, Belgium, TNS opinion. https://doi.org/10.4232/1.13159

European Union (2013). The Sharing Economy. Accessibility Based Business Models for Peer-toPeer Markets, Case study 12, European Commission, Business Innovation Observatory, Contract No 190/PP/ENT/CIP/12/C/N03C01.

European Union (2018a 23 February). Study to Monitor the Economic Development of the Collaborative Economy at sector level in the 28 EU Member States. Final Report, European commission, B-1049 Brussels, Luxembourg: Publications Office of the European Union, ISBN: 978-92-79-81728-1. https://doi.org/10.2873/83555

European Union. (2018b). Study to Monitor the Economic Development of the Collaborative Economy in the EU. European Commission, Directorate-General for Directorate-General for Internal Market, Industry, Entrepreneurship and SMEs Framework Contract ENTR/172/PP/2012/FC - lot1, Luxembourg: Publications Office of the European Union, ISBN 978-92-79-81728-1.

EY (2015, October). The rise of the sharing economy The Indian landscape. https://www.ey.com/in 
Frenken, K., \& Schor, J. (2017). Putting the Sharing Economy into Perspective. Environmental Innovation and Societal Transitions, 23, 3-10. https://doi.org/10.1016/j.eist.2017.01.003

Gawel, A., Machur, W., \& Pennington, J. (2016). Industry Agenda: Understanding the sharing economy. World Economic Forum.

Görög, G. (2018). The definitions of sharing economy: A systematic literature review. Management, 13(2), $175-189$

Goudin, P. (2016 January). The Cost of Non-Europe in the Sharing Economy - Economic, Social and Legal Challenges and Opportunities. EPRS - European Parliamentary Research Service, European Added Value Unit, European Parliament, PE 558.777.

Lee, H. R., Kim, M. J., Kim, Lee, H. R., \& Hwang, S. (2016). An Economic Analysis of the Sharing Economy: Benefits, Concerns and Policy Implications. KDI Research Monograph.

Stokes, K., Clarence, E., Anderson, L., \& Rinnie, A. (2014 September). Making sense of the UK collaborative economy. https://www.nesta.org.uk

Martin, C. J. (2015). The Sharing Economy: A Pathway to Sustainability Or a New Nightmarish Form of Neoliberalism?. Ecological Economics, 121, 149159. https://doi.org/10.1016/j.ecolecon.2015.11.027

Matofska, B. (2015 March). What We Know About Sharing Economy. Founder, Compare and Share. https://www.compareandshare.com
Pérez-Pérez, C., Benito-Osorio, D., García-Moreno, S.M., \& Martínez-Fernández, A. (2021). Is Sharing a Better Alternative for the Planet? The Contribution of Sharing Economy to Sustainable Development Goals. Sustainability, 13, 1843. https://doi.org/10.3390/su13041843.

Petropoulos, G. (2017). An economic review of the collaborative economy. Bruegel Policy Contribution, 5, 1-17.

Slee, T. (2015). What's Yours Is Mine: Against the Sharing Economy. OR Books.

Stephany, A. (2015). The Business of Sharing: Making it in the New Sharing Economy. Palgrave Macmillan.

Stojković, M. (2019). Utjecaj ekonomije dijeljenja na promjene u transportnom ponašanju starije populacije (eng. The influence of the sharing economy of on changes in the transport behavior of the older population). Diplomski rad. Sveučilište u Zagrebu, Ekonomski fakultet, Diplomski sveučilišni studij Poslovne ekonomije, Trgovina i međunarodno poslovanje, Zagreb.

Sundararajan, A. (2016). The sharing economy. The end of employment and the rise of crowd-based capitalism. Massachusetts, MIT Press.

Yaraghi, N., \& Shamika, R. (2017). The Current and Future State of the Sharing Economy. Brookings India.

\section{EKONOMIJA DELJENJA NA NIVOU EVROPSKE UNIJE: STANJE I PERSPEKTIVE}

Uopšteno govoreći, ekonomija deljenja, kao brzorastući i fenomen novijeg datuma, uključuje razmenu resursa pomoću internet platforme za proizvodnju, distribuciju i pružanje novih usluga. Imajući u vidu njen snažan uticaj na oblikovanje budućih politika tržišta rada, radnih odnosa, obrazovanja i obuke, kao i na digitalizaciju, nema sumnje da je ekonomija deljenja jedna od atraktivnih tema na današnjoj političkoj agendi, ne samo u Evropi, već i širom sveta. Moglo bi se slobodno reći da je ekonomija deljenja u Evropskoj uniji vrlo aktuelna tema, kao i da o njoj kruže brojni radovi, što sve upućuje na opšti zaključak da ovaj novi model nije i dalje razvijen na smislen način u ovom delu sveta. U tom smislu, primarni cilj ovog rada jeste da se primenom naučnih metoda sistematizacije i analize istraži mehanizam funkcionisanja ekonomije deljenja, sa posebnim naglaskom na mogućnosti i ograničenja njenog razvoja na nivou EU. Rad sugeriše da ekonomija deljenja još uvek nije doživela svoj puni zamah na nivou EU, dok istovremeno nudi zaključke i preporuke u vezi sa boljim iskorišćenjem njenog razvojnog potencijala u ovom delu sveta. Nalazi rada upućuju na to da EU ima pozitivan stav prema ekonomiji deljenja, smatrajući je prilikom, a nikako pretnjom, iako postoji ogroman prostor za dalji napredak i ekonomsku ekspanziju ovog poslovnog modela (u smislu zapošljavanja, rasta, konkurentnosti, održivosti i prelaska na cirkularnu ekonomiju), kao i za značajan pomak u oblasti njene regulacije kako bi se u narednom periodu izbegle ozbiljne bifurkacije. Kako bi ekonomija deljenje na nivou EU u nastupajućem periodu napravila ogromne pomake napred, najvažnije je uspostaviti dinamično pravno okruženje kako bi se izbegao rizik od fragmentacije jedinstvenog tržišta i nelojalne konkurencije.

Ključne reči: Ekonomija deljenja; Evropska unija; Regulacija; Trajna održivost; COVID-19, 